\title{
Transatlantica
}

Revue d'études américaines. American Studies Journal

1| 2021

Line Breaks in America: the Odds and Ends of Poetry

\section{Plage Critique}

\section{Vincent Broqua}

\section{OpenEdition}

Journals

Édition électronique

URL : https://journals.openedition.org/transatlantica/17349

DOI : $10.4000 /$ transatlantica. 17349

ISSN : 1765-2766

Éditeur

Association française d'Etudes Américaines (AFEA)

Référence électronique

Vincent Broqua, «Plage Critique », Transatlantica [En ligne], 1 | 2021, mis en ligne le 01 juillet 2021, consulté le 04 février 2023. URL : http://journals.openedition.org/transatlantica/17349 ; DOI : https:// doi.org/10.4000/transatlantica. 17349

Ce document a été généré automatiquement le 4 février 2023

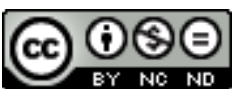

Creative Commons - Attribution - Pas d'Utilisation Commerciale - Pas de Modification 4.0 International - CC BY-NC-ND 4.0

https://creativecommons.org/licenses/by-nc-nd/4.0/ 


\title{
Plage Critique
}

\author{
Vincent Broqua
}

\section{Plage critique}

Fin de vers, prose, théâtre et disturbance

Ce texte a une double situation de départ. Il est écrit pour le dossier de Chloé Thomas sur la fin de vers et l'enjambement. Il a été élaboré lors d'une séance de mon séminaire doctoral de recherchecréation à Paris 8. Le propos de cette séance menée par des doctorant.e.s était de faire jouer ensemble un texte de théorie et un texte littéraire.

Suivant cette consigne, mon texte est une manière de réfléchir aux enjeux de la prose et du vers, du rythme, des langues, tout autant qu'à ce qui gouverne l'écriture ou non.

Le fantasme consistait à lire ensemble The 3:15 Experiment (The Owl Press, 2001) de Bernadette Mayer, Lee Ann Brown, Jen Hofer et Danika Dinsmore avec Roland Barthes, Comment vivre ensemble (Seuil/IMEC, 2002), particulièrement les passages sur l'idiorrythmie. Dans The 3:15 Experiment, les quatre poètes écrivent ensemble et seules à 3:15 où qu'elles se trouvent. Le fantasme consistait à se demander par l'écriture créative quel rapport la fin de vers et l'enjambement entretiennent à l'idiorrythmie.

Ce qui suit est en partie un montage des pages 36-40 du séminaire de Barthes, soit la partie intitulée "Mon Fantasme : l'idiorrythmie ${ }^{1}$ ", et d'un ensemble de fragments pris en dérivant dans le livre des quatre poètes. J'ai conçu ce texte en dialogue avec les deux frèsh critiques.

\section{Introduction}

Tout d'abord, je propose que nous envisagions deux scènes pour la petite comédie d'aujourd'hui : là

et

là

Et une question

qui peut être une prophétie :

l'expérience du rituel collectif sans communion est-il un érémitisme de papier? 
ou

la fin de vers

est-elle au poème

ce que la vie érémitique est

au rythme d'une communauté ?

or

if we are the labor

of poetry, then who is management

when laws govern it

$1^{\text {ère }}$ partie, première scène.

Il faut bien comprendre que pour qu'il y ait fantasme, il faut qu'il y ait scène (scénario), donc lieu. Le détour de la fin de vers. Expérience du rituel collectif.

They say timing is a gift.

Like Turquoise. Sky should

pull over \& share the

duet

«c'est en mettant ensemble deux rythmes différents que l'on crée de profondes disturbances. »

$=$ traduction $=$

When you pull together two

timing like turquoise you

should share moving duet

Athos (où je ne suis jamais allé) procure un mixte d'images : Méditerranée, terrasse, montagne (dans le fantasme, on oblitère ; ici la crasse, la foi).

Un trou mais pas au milieu, des ponctuations mais agrammaticales, des corps asyntaxes sur des plages critiques. Au fond, c'est un paysage. Je me vois là, au bord d'une terrasse, la mer au loin, le crépi blanc, disposant de deux chambres à moi et autant pour quelques amis, non loin + une occasion de synaxe. (...) (sic, il dit bien synaxe).

A rock \& roll

star.

Excursus : "mouvement régulier des flots »! Or l'histoire du mot: Jusqu'à la période attique, rhuthmos ne signifie jamais "rythme", n'est pas appliqué au mouvement régulier des flots. Le sens est : forme distinctive, figure proportionnée, disposition ; Ce souvenir étymologique nous importe :

Familiar but late

Someone's kept 
me in the

dark on this

(...)

$2^{\mathrm{e}}$ partie, deuxième scène.

late and dark I want to disappear into

the general you who you be me we and

this spiritual longing spiritual awakening spiritual

loneliness has occurred will occur because (...)

à l'autre extrémité de la scène, également dans l'ombre : les macro-groupements, les grandes communes, les phalanstères, les couvents, le cénobitisme. Pourquoi ? je veux dire: pourquoi le fantasme ne rencontre pas ces grandes formes? Evident: parce qu'elles sont structurées selon une architecture de pouvoir (j'y reviendrai), avec leur timing de quart d'heure en quart d'heure : casernes, internats.

What happens at 3:15?

one clock says $3: 17$

but it's probably fast

\section{Conclusion}

Disons encore : nous cherchons une zone entre deux formes excessives :

1) une forme excessive négative : la solitude, l'érémitisme,

The ticking double, fractured, unframed

pulled apart to unravel

2) une forme excessive intégrative : le coenobium (laïque ou non),

Are people we do and don't know both

and the sound of a different am

(so we don't need to go other places)

une forme médiane, utopique, édénique, idyllique

I

was dreaming of four separate

men each I love

with different breath and

Notons que cette forme est très excentrique : n'a jamais bien pris dans l'Église (au mont Athos, en déshérence), qui en fait l'a toujours combattue. D'autre part, la psychanalyse n'a pas mordu sur les « petits groupes».

Let's pick up there we (sic, elle dit bien « there we »)

left off 
I said globe and you

These are prophecies of my

youth. And so good night

\section{critical beach / critical track \\ Endline, prose, theatre, and disturbance}

This text emerges from a double situation. It was written for Chloé Thomas' dossier on endline and run-on-lines. And it was written during a session of my doctoral researchcreation seminar at Paris 8 . The purpose of that session, led by doctoral students, was to confront a theoretical text and a literary text.

In line with this instruction, my text is a way of thinking about the stakes of prose and verse, rhythm, languages, as well as about what governs writing (or not).

The fantasy was to read The 3:15 Experiment (The Owl Press, 2001) by Bernadette Mayer, Lee Ann Brown, Jen Hofer and Danika Dinsmore with Roland Barthes's Comment vivre ensemble (Seuil/IMEC, 2002), especially the passages on what he calls idiorrhythmy, and vice-versa. In The 3:15 Experiment, the four poets write together and alone at 3:15 wherever they are. The fantasy was to ask through creative writing what relationship there might be between endlines and enjambments and idiorrhythmy.

What follows is in part a montage of pages 36-40 of Barthes' seminar, the section entitled "My Fantasy: Idiorrhythmy," and a set of fragments taken from the four poets' book. I conceived this text in dialogue with what I call my frèsh critiques.

Introduction :

First, I propose that we consider two scenes for today's little comedy: there and there.

And a question

which may be

a prophecy:

Does the experience of a collective ritual-without-communion amount to a paper eremitism?

or

are endlines

to the poem

what the eremitic life is

to the rhythm of a community? 
or

if we are the labor

of poetry, then who is management

when laws govern it

\section{$1^{\text {st }}$ part, first scene.}

It is necessary to understand that for a fantasy to appear, one needs a scene (a scenario), and thus a place. The detour of endlines. An experience of collective ritual.

They say timing is a gift.

Like Turquoise. Sky should

pull over \& share the

duet

«c'est en mettant ensemble deux rythmes différents que l'on crée de profondes disturbances. »

$=$ translation $=$

When you pull together two

timing like turquoise you

should share moving duet

Athos (where I've never been) creates a mixture of images: Méditerranée, terrasse, mountain (in fantasies, you obliterate ; filth, faith).

A hole. Not in the middle though. Punctuation yet agrammatical. Asyntactical bodies on critical beaches. Come to think of it, it is a landscape. I see myself there, at the edge of a terrace, with the sea in the distance, white walls, and two rooms for myself and two others for friends, not far + an opportunity for synaxis. (...)

A rock \& roll

star.

Excursus : "the regular movement of the waves"! actually, the history of the word: until the Attic period, rhuthmos has never meant "rhythm", it was not applied to the regular movement of the waves. The meaning was: distinctive form, proportioned figure, disposition; This etymological memory is important to us:

Familiar but late

Someone's kept

me in the

dark on this

(...) 


\section{$2^{\text {nd }}$ part, second scene.}

late and dark I want to disappear into

the general you who you be me we and

this spiritual longing spiritual awakening spiritual

loneliness has occurred will occur because (...)

at the other end of the stage, also in the shadows: the macro-groups, the large communes, the phalansteries, the convents, cenobitism. Why? I mean, why doesn't the fantasy encounter these large forms? Obvious: because they are structured according to an architecture of power (I will come back to this), with their 15min period timing: barracks, boarding schools.

What happens at $3: 15$ ?

one clock says 3:17

but it's probably fast

\section{Conclusion}

Let us say it again: we are looking for a zone between two forms of excess:

1) a negative form of excess: solitude, eremitism, The ticking double, fractured, unframed pulled apart to unravel

2) an integrative form of excess: coenobium (secular or not), Are people we do and don't know both and the sound of a different am (so we don't need to go other places)

an inbetween, utopian, Edenic, idyllic form

$$
\text { I }
$$

was dreaming of four separate

men each I love

with different breath and

Let us note that this form is very eccentric: it was never totally admitted in the Church (on Mount Athos, in disuse), in fact the Church has always fought it. On the other hand, psychoanalysis was not into the "small groups".

Let's pick up there we

(sic, she does say «there we »)

left off

I said globe and you

These are prophecies of my

youth. And so good night 


\section{NOTES}

1. Roland Barthes, Comment vivre ensemble: simulation romanesque de quelques espaces quotidiens. Cours et séminaires au Collège de France 1976-1977), Seuil - IMEC, 2002. (Note de l'éditrice).

\section{AUTEUR}

\section{VINCENT BROQUA}

Université Paris 8, TransCrit (EA1569) 